\title{
INFLUENCE OF INFLATION, INTEREST RATE AND CURRENCY ON COMPOSITE STOCK SHARE PRICE INDEX LISTED IN INDONESIA OF STOCK EXCHANGE JAKARTA
}

\author{
Nurhana Dhea Parlina \\ Abdul Haris \\ Erwin Budianto \\ University of Swadaya Gunung Jati \\ nurhana_dp@yahoo.com
}

\begin{abstract}
Inflation, interest rate and currency are factors that influence the (IHSG) Composite Stock Share Price Index. Above also explains, if Inflation rates rise then the Composite Stock Share Price Index will go up, but we see that the theory will not be the same forever with the practice or application. For that we intend to see if it was true what was mentioned by the theory. To find out we took Composite Stock Share Price Index data that listed on Indonesia Stock Exchange from the period 1 January 2013 - until 31 December 2015. Then we took the Inflation rate and interest rate data from the period 1 January 2013 until 31 December 2015. Inflation, interest rate and currency are of economic factors can influence Composite Stock Share Price Index. If the inflation and interest rate more high than before it can impact of Composite Stock Share Price Index. Otherwise, In this study we will examine Composite Stock Share Price Index from the results obtained output of coefficient over than 0.05 as much as 0.306 so the final inflation, interest rate and currency aren't influence of Composite Stock Share Price.
\end{abstract}

Keywords : Inflation, Interest Rate, Currency and IHSG.

\section{PENDAHULUAN}

Perekonomian Indonesia ditunjang dari beragai aktivitas terutama dalm segi investasi seperti yang kita ketahui bahwa dalam konsep investasi terdapat komitmen, expected return dan resiko sehingga kita harus lebih waspada terhadap apa yang akan terjai dikemudian hari. Oleh karena itu, dengan adanya variabel ekonomi yang mempengaharuhi dari proses kegiatan investasi diantaranya yang pertama adalah inflasi dirasakan sangat mencekik kondisi investor kecil dalam berinvestasi karena semakin meningkatnya kebutuhan akan dana yang diinvestasikan dengan nilai waktu dan uang terutama pada bulan Agustus 2013 terjadi inflasi sebesar $8,79 \%$ dengan rata-rata inflasi $6,59 \%$. Sedangkan suku bunga meningkat pada bulan November 2014 sebesar 7,63\% serta nilai kurs rupiah terhadap dolar di akhir bulan Desember 2015 meningkat tajam sebesar Rp. 13.885,- yang pada akhirnya akan mempengaruhi nilai indek harga saham gabungan secara keseluruhan pada bulan September 2015 sebesar 4326.61 terjadi sedikit 
penurunan dibandingkan harga indeks saham gabungan sebelumnya yang dapat mempengaruhi volatilitas pergerakan indek harga saham gabungan. Oleh karena itu dibutuhkan kinerja ihsg yang sesuai dengan kondisi perekonomian pada saat ini yang mempengaruhi iklim investasi. oleh karena itu peneliti tertarik untuk mengambil judul Pengaruh Inflasi, Suku Bunga, dan Kurs Terhadap Indeks Harga Saham Gabungan Yang Terdaftar Di BEI Jakarta. Berdasarkan latar belakang tersebut, maka pada penelitian ini ingin mengetahui masalahnya yaitu Apakah Inflasi, Suku Bunga, Kurs berpengaruh pada Harga Saham Gabungan.

\section{KERANGKA TEORITIS DAN HIPOTESIS}

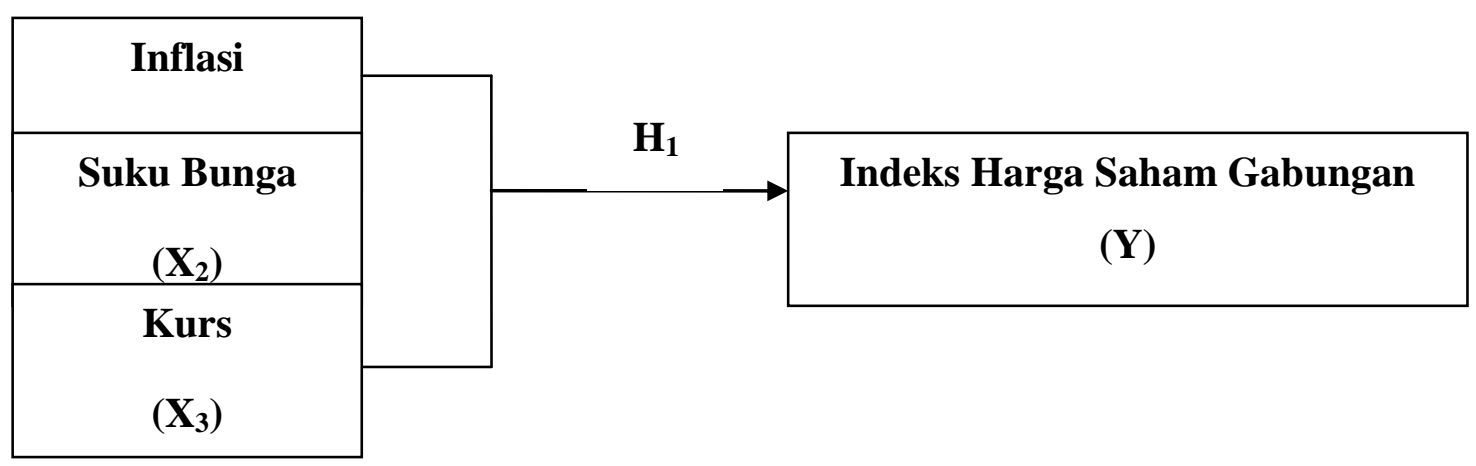

Gambar 1. Paradigma Penelitian

Hipotesis dan Hasil Penelitian Terdahulu

Murtianingsih (2012) dengan Inflasi tidak mempunyai pengaruh yang signifikan terhadap harga saham perusahaan Sektor Properti dan Real Estate di Bursa Efek Indonesia. Artinya walaupun inflasi mengalami kenaikkan atau penurunan tidak berpengaruh terhadap harga saham perusahaan Sektor Properti dan Real Estate. Suramaya (2012) mengemukakan bahwa Penelitian ini menemukan bahwa tingkat inflasi, suku bunga SBI dan pertumbuhan PDB tidak memiliki pengaruh yang signifikan terhadap IHSG, sedangkan kurs rupiah berpengaruh negatif dan signifikan terhadap IHSG.

Maghyereh (2002) meneliti hubungan yang bersifat jangka panjang antara harga saham dan variabel ekonomi makro di Jordania yang diawali oleh Johansen's (1998) menggunakan analisa data time series dengan periode januari 1987 sampai Desember 2000. Hasil penelitian menunjukkan bahwa variabel ekonomi makro merefleksikan harga saham di pasar modal Jordania. Maysami and Koh (2000) dalam penelitiannya di singapura menyatakan inflasi, pertumbuhan penawaran uang, suku bunga jangka pendek dan jangka panjang dan nilai tukar mempengaruhi perubahan harga sama di singapura. Murtianingsih (2012) mengemukakan bahwa Hasil penelitian menemukan bahwa inflasi, suku Bunga BI, Nilai Tukar mata uang terhadap Dolar berpengaruh signifikan terhadap pergerakan IHSG.

H1 : Terdapat pengaruh Inflasi, Suku Bunga dan Kurs terhadap Indeks Harga Saham Gabungan

METODOLOGI 
Dalam penelitian ini dapat dikatakan termasuk kedalam jenis penelitian kuantitatif. Penelitian kuantitatif merupakan studi yang diposisikan sebagai bebas nilai (value free) Objek yang diteliti berupa data indeks harga gabungan yang terdaftar di BEI Jakarta yang dapat di download melalui website

www.duniainvestasi.com dan data inflasi, suku bunga dan kurs yang diperoleh melalui website : www. bi.go.id dan pada www.kontan.co.id periode bulan Januari 2013 sampai dengan Desember 2015. Sedangkan kurs Metode penelitian yang digunakan dalam penelitian ini adalah menggunakan studi kausal adalah menentukan sebab akibat yang definitif. Unit observasi dalam penelitian ini adalah data indeks harga gabungan yang terdaftar di BEI Jakarta dan data inflasi pada periode bulan Januari 2013 sampai dengan Desember 2015 yang terdaftar di Bursa Efek Indonesia (BEI). Sampel yang digunakan dalam penelitian ini adalah data inflasi dan indeks harga saham gabungan dengan periode waktu perbulan selama 3 tahun. $\mathrm{N}=12 \times 3=$ 36 bulan. Menurut Roscoe (1975) dalam sekaran (2006 :160) mengemukakan bahwa untuk pengukuran sampel lebih dari 30 dan kurang dari 500 adalah tepat untuk kebanyakan penelitian. Sampel yang digunakan dalam penelitian ini diambil dengan metode purposive sampling yaitu sampel dipilih berdasarkan pada kesesuaian karakteristik dengan kriteria sampel yang ditentukan agar diperoleh sampel yang representatif. Hal tersebut diungkapkan oleh Sekaran (2014:164) Kriteria tersebut antara lain :

1. Indek Harga Saham Gabungan yang terdaftar (listing) di Bursa Efek Indonesia dari tahun 2013 - 2015

2. Data IHSG yang didapat satu tahun terakhir dari tahun 2016

3. Data IHSG bersifat per bulan

Tabel 1

Operasional Variabel

\begin{tabular}{|c|c|}
\hline Variabel & Definisi Operasional \\
\hline $\begin{array}{l}\text { Independen : (LN bentuk } \\
\text { rupiah) } \\
\text { 1. Inflasi (LN) } \\
\text { 2. Suku Bunga (LN) } \\
\text { 3. Kurs (rupiah) }\end{array}$ & $\begin{array}{l}\text { Besarnya tingkat inflasi (\%) } \\
\text { Besarnya tingkat suku bunga yang ditetapkan oleh } \\
\text { Bank Indonesia (\%) } \\
\text { Besarnya nilai (kurs tengah Bank Indonesia) }\end{array}$ \\
\hline $\begin{array}{l}\text { Dependen : (rupiah) } \\
\text { 4. Indeks Harga Saham Gabungan }\end{array}$ & Indeks harga saham penutupan (closing price) \\
\hline
\end{tabular}

Semua data yang digunakan dalam penelitian ini adalah data sekunder. Data sekunder adalah data yang pengumpulan dan publikasinya dilaksanakan oleh pihak lain. Menurut waktu pengumpulannya, penelitian ini menggunakan data time series, yaitu data yang dikumpulkan selama 14 beberapa periode dengan tujuan untuk mengetahui arah perubahannya (trend). Data yang digunakan dalam penelitian ini adalah data sekunder berupa data sekunder yang merupakan data kuantitatif melalui website data Bank Indonesia dan Dunia Investasi. 
Analisis regresi pada dasarnya adalah studi mengenai kebergantungan variabel dependen (terikat) dengan salah satu atau lebih variabel independen (variabel penjelas/bebas), dengan tujuan mengestimasi dan/atau memprediksi rata-rata populasi atau nilai rata-rata variabel dependen berdasarkan nilai variabel independen yang diketahui, hal tersebut dikemukakan oleh (Gujarati, 2003) yang dikutip dalam bukunya oleh Ghozali (2011:95).

Hasil analisis regresi adalah berupa koefisien untuk masing-masing variabel independen. Koefisien ini diperoleh dengan cara memprediksi nilai variabel independen dengan suatu persamaan. Koefisien regresi dihitung dengan dua tujuan sekaligus menurut (Tabachnick, 1996) yang dikutip dalam bukunya oleh Ghozali (2011:95) adalah sebagai berikut : Meminimumkan penyimpangan antara nilai aktual Nilai estimasi variabel independen berdasarkan data yang ada.

$$
\text { Metode analisis data }
$$
menggunakan analisis data regresi linier berganda, analisis regresi pada dasarnya adalah studi mengenai kebergantungan variabel dependen (terikat) dengan salah satu atau lebih variabel independen (variabel penjelas/bebas), dengan tujuan mengestimasi dan/atau memprediksi rata-rata populasi atau nilai rata-rata variabel dependen berdasarkan nilai variabel independen yang diketahui, hal tersebut dikemukakan oleh (Gujarati, 2003) yang dikutip dalam bukunya oleh Ghozali (2011:95).

Hasil analisis regresi adalah berupa koefisien untuk masing-masing variabel independen. Koefisien ini diperoleh dengan cara memprediksi nilai variabel independen dengan suatu persamaan. Koefisien regresi dihitung dengan dua tujuan sekaligus menurut

(Tabachnick, 1996) yang dikutip dalam bukunya oleh Ghozali (2011:95) adalah sebagai berikut :

(1) Meminimumkan penyimpangan antara nilai aktual

(2) Nilai estimasi variabel independen berdasarkan data yang ada

Namun, sebelum dilakukan regresi linier sederhana dengan menggunakan alat bantu software SPSS 21 salah satu variabel di Ln kan terlebih dahulu agar memiliki kesamaan dalam skala pengukuranya dengan menggunakan alat bantu microsof excel.

Uji Asumsi Klasik

1. Multikolinieritas bertujuan untuk menguji apakah model regresi apakah model regresi ditemukan adanya korelasi antar variabel bebas (independen).

2. Normalitas bertujuan untuk menguji apakah dalam model regresi variabel penganggu atau residual memiliki distribusi normal.

3. Heteroskedastisitas bertujuan menguji apakah dalam model regresi terjadi ketidaksamaan variance dari residual satu pengamatan ke pengamatan yang lain.

4. Autokorelasi bertujuan menguji apakah dalam model regresi linier ada korelasi kesalahan variabel penganggu pada periode $\mathrm{t}-1$ (sebelumnya).

Tabel 2. Model Summary

\begin{tabular}{|l|r|r|r|c|}
\hline Model & R & R Square & $\begin{array}{c}\text { Adjusted R } \\
\text { Square }\end{array}$ & $\begin{array}{c}\text { Std. Error of the } \\
\text { Estimate }\end{array}$ \\
\hline 1 & $.324^{\mathrm{a}}$ & .105 & .021 & 344.86741 \\
\hline
\end{tabular}

a. Predictors: (Constant), x3_kurs, x1_inflasi, x2_sukubunga 


\section{HASIL DAN PEMBAHASAN}

Dari tampilan output SPSS pada tabel 2 model summary diatas besarnya Adjusted R Square adalah 0.021, hal ini berarti $2.1 \%$ variasi IHSG dapat dijelaskan oleh variasi inflasi dan suku bunga. Sedangkan sisanya (100\% $2.1 \%=97.9 \%$ ) disebabkan oleh sebabsebab lain diluar model. Standar error of estimate sebesar 344.86. Semakin besar nilai SEE akan membuat model regresi semakin kurang tepat dalam memprediksi variabel dependen.

Tabel 3. ANOVA ${ }^{\mathrm{a}}$

\begin{tabular}{|c|c|c|c|c|c|c|}
\hline \multicolumn{2}{|c|}{ Model } & $\begin{array}{c}\text { Sum of } \\
\text { Squares }\end{array}$ & $\overline{\mathrm{Df}}$ & $\begin{array}{c}\text { Mean } \\
\text { Square }\end{array}$ & $\bar{F}$ & Sig. \\
\hline \multirow{3}{*}{1} & Regression & 447669.839 & 3 & 149223.280 & 1.255 & $.306^{\mathrm{b}}$ \\
\hline & Residual & 3805873.023 & 32 & 118933.532 & & \\
\hline & Total & 4253542.862 & 35 & & & \\
\hline
\end{tabular}

a. Dependent Variable: y_ihsg

b. Predictors: (Constant), x3_kurs, x1_inflasi, x2_sukubunga

Dari tampilan output SPSS pada tabel 3 ANOVA atau $F$ test didapat nilai $\mathrm{F}$ hitung sebesar 1.255 dengan probablilitas 0.306. Karena probabilitas jauh lebih besar dari 0.05 maka model regresi dapat digunakan untuk memprediksi IHSG atau dapat dikatakan bahwa inflasi dan suku bunga secara bersama-sama tidak berpengaruh terhadap IHSG.

Tabel 4 Coefficients ${ }^{\mathrm{a}}$

\begin{tabular}{|rl|r|r|r|r|r|}
\hline \multicolumn{1}{|l|}{ Model } & \multicolumn{2}{|c|}{$\begin{array}{c}\text { Unstandardized } \\
\text { Coefficients }\end{array}$} & $\begin{array}{c}\text { Standardized } \\
\text { Coefficients }\end{array}$ & \multirow{2}{*}{ Sig. } & \\
\cline { 2 - 4 } & \multicolumn{1}{|c|}{ B } & \multicolumn{1}{c|}{ Std. Error } & \multicolumn{1}{c|}{ Beta } & & \\
\hline \multirow{2}{*}{1} & (Constant) & 4404.555 & 2561.025 & & 1.720 & .095 \\
& x1_inflasi & 367.427 & 251.332 & .253 & 1.462 & .154 \\
& x2_sukubunga & -388.324 & 783.732 & -.115 & -.495 & .624 \\
& x3_kurs & .035 & .064 & .124 & .541 & .592 \\
\hline
\end{tabular}

a. Dependent Variable: y_ihsg

Dari tampilan output SPSS berdasarkan pada tabel 4 coefficient diatas didapat dengan persamaan matematis adalah sebagai berikut :

IHSG $=4404.555+367.427$ INFLASI 388.324 SUKU BUNGA + 0.035 KURS

Dari hasil nilai persamaan regresi diatas dapat diambil kesimpulan bahwa :

1. Konstant sebesar menyatakan bahwa jika variabel independen dianggap konstan maka rata-rata harga indeks saham gabungan sebesar 4404.555.
2. Koefisien regresi inflasi sebesar 367.427 menyatakan bahwa setiap harga indeks saham gabungan meningkat maka akan meningkatnya harga sebesar 1000 rupiah akan meningkatkan nilai presentase IHSG sebesar 367427 rupiah. Suku bunga akan menurun dalam Koefisien regresi suku bunga sebesar -388.324 menyatakan bahwa setiap harga indeks saham gabungan menurun maka akan menurunnya nilai presentase suku bunga. Koefisien 
regresi kurs sebesar 0.035 menyatakan bahwa setiap harga indeks saham gabungan meningkat maka akan meningkatnya harga sebesar 1000 rupiah akan meningkatkan nilai presentase IHSG sebesar 35 rupiah.

Hasil diatas dapat disimpulkan bahwa inflasi dan suku bunga tidak berpengaruh terhadap indeks harga saham gabungan. hal ini tidak sejalan menurut beberapa pendapat para ahli diantaranya adalah : Maghyereh (2002) meneliti hubungan yang bersifat jangka panjang antara harga saham dan variabel ekonomi makro di Jordania yang diawali oleh Johansen's (1998) menggunakan analisa data time series dengan periode januari 1987 sampai Desember 2000. Hasil penelitian menunjukkan bahwa variabel ekonomi makro merefleksikan harga saham di pasar modal Jordania. Maysami and Koh (2000) dalam penelitiannya di singapura menyatakan inflasi, pertumbuhan penawaran uang, suku bunga jangka pendek dan jangka panjang dan nilai tukar mempengaruhi perubahan harga sama di singapura.

Sedangkan hal jalan menurut Murtianingsih (2012) dengan Inflasi tidak mempunyai pengaruh yang signifikan terhadap harga saham perusahaan Sektor Properti dan Real Estate di Bursa Efek Indonesia. Artinya walaupun inflasi mengalami kenaikkan atau penurunan tidak berpengaruh terhadap harga saham perusahaan Sektor Properti dan Real Estate. Suramaya (2012) mengemukakan bahwa Penelitian ini menemukan bahwa tingkat inflasi, suku bunga SBI dan pertumbuhan PDB tidak memiliki pengaruh yang signifikan terhadap IHSG, sedangkan kurs rupiah berpengaruh negatif dan signifikan terhadap IHSG.

\section{Uji Asumsi Klasik}

\section{Multikolinieritas}

Tabel 5. Coefficients

\begin{tabular}{|c|c|c|c|c|c|c|c|}
\hline \multirow[t]{2}{*}{ Model } & \multicolumn{2}{|c|}{$\begin{array}{c}\text { Unstandardized } \\
\text { Coefficients }\end{array}$} & \multirow{2}{*}{$\begin{array}{c}\text { Standardized } \\
\text { Coefficients } \\
\text { Beta }\end{array}$} & \multirow[t]{2}{*}{$t$} & \multirow[t]{2}{*}{ Sig. } & \multicolumn{2}{|c|}{ Collinearity Statistics } \\
\hline & $\mathrm{B}$ & Std. Error & & & & Tolerance & VIF \\
\hline (Constant) & 4404.555 & 2561.025 & & 1.720 & .095 & & \\
\hline $\mathrm{x} 1$ inflasi & 367.427 & 251.332 & .253 & 1.462 & .154 & .931 & 1.074 \\
\hline x2_sukubunga & -388.324 & 783.732 & -.115 & -.495 & .624 & .516 & 1.938 \\
\hline x3_kurs & .035 & .064 & .124 & .541 & .592 & .529 & 1.889 \\
\hline
\end{tabular}

a. Dependent Variable: $y \_$insg

Hasil perhitungan tabel 6 diatas dapat disimpulkan bahwa nilai tolerance kurang dari 0.10 yang berarti tidak ada korelasi antar variabel independen yang nilainya lebih dari 95\%. Hasil perhitungan nilai Variance Inflation Factor (VIF) juga menunjukkan hal yang sama tidak ada satu variabel independen yang memiliki nilai VIF lebih dari 10. Jadi dapat disimpulkan bahwa tidak ada multikolonieritas antar variabel independen dalam model regresi.
2. Normalitas.

Dari gambar 2 bahwa grafik normalitas dibawah menunjukkan bahwa data mendekati dan mengikuti arah garis diagonal atau grafik histrogram memperlihatkan pola distribusi normal, maka model regresi memenuhi asumsi normalitas. 
Gambar 2. Grafik Normalitas Plot

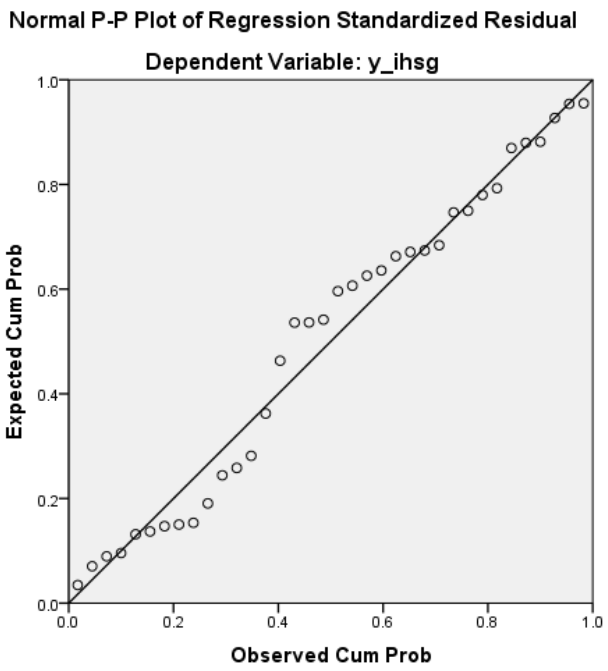

3. Heteroskedastisitas

Dari gambar 3 grafik scater plot diatas terlihat titik titik menyebar secara acak serta menyebar secara acak serta tersebar baik diatas ataupun dibawah angka 0 pada sumbu Y. Hal ini dapat disimpulkan bahwa tidak terjadi heteroskedastisitas pada model regresi ini.

Gambar 3. Grafik Scatterplot

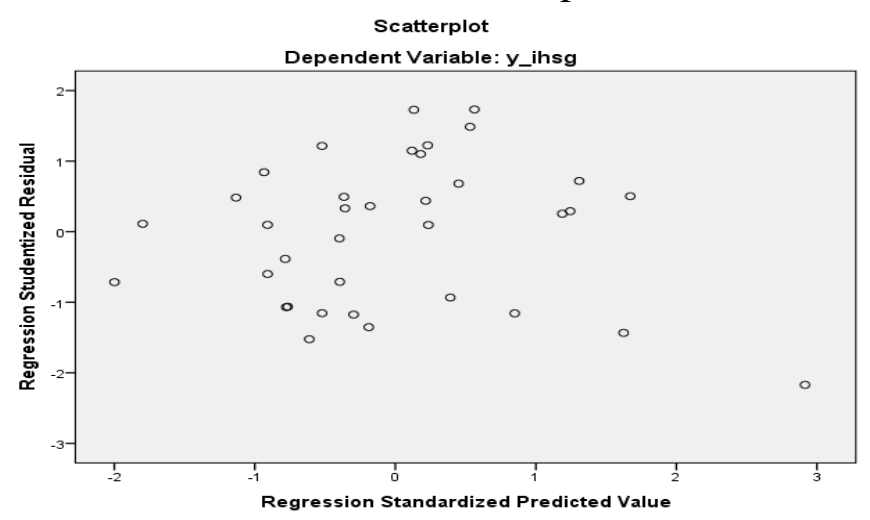

4. Autokorelasi

Tabel 7. Model Summary ${ }^{\mathfrak{b}}$

\begin{tabular}{|l|r|r|r|r|r|}
\hline Model & $\mathrm{R}$ & $\mathrm{R}$ Square & $\begin{array}{c}\text { Adjusted R } \\
\text { Square }\end{array}$ & $\begin{array}{c}\text { Std. Error of the } \\
\text { Estimate }\end{array}$ & Durbin-Watson \\
\hline 1 & $.324^{\mathrm{a}}$ & .105 & .021 & 344.86741 & .226 \\
\hline
\end{tabular}

a. Predictors: (Constant), x3_kurs, x1_inflasi, x2_sukubunga

b. Dependent Variable: $y \_$insg

Nilai DW sebesar 0.226, nilai ini akan kita bandingkan dengan nilai tabel 7 dengan menggunakan nilai signifikansi 5\%, jumlah sampel 36 (n) dengan jumlah variabel independen 3 $(\mathrm{k}=3)$, maka tabel DW akan didapatkan sebesar $1.654>$ dari DW 0.226 dan kurang dari (3 - du) perhitungannya adalah sebagai berikut $3-1.654=$ 1.346 artinya tidak terdapat autokorelasi positif atau negatif. 


\section{KESIMPULAN DAN IMPLIKASI PENELITIAN}

Hasil penelitian ini dapat disimpulkan bahwa adanya penemuan akhir bahwa inflasi, suku bunga, dan kurs tidak berpengaruh terhadap IHSG karena laju inflasi selama pada periode bulan Januari 2013 sampai dengan Desember 2015 volatilitasnya masih dalam ambang batas kewajaran.

Kebijakan moneter yang ditetapkan pemerintah dapat menjadikan perekonomian Indonesia tumbuh dan disertai dengan iklim investasi yang baik di sektor riil sehingga pergerakan harga saham IHSG mengalami peningkatan setiap tahunnya.

Variabel ekonomi makro sebagai fundamental teknikal yang merupakan hal yang harus diperhatikan investor selain dalam menentukan keputusan investasi terutama investasi dalam jangka pendek. Pasar modal di Indonesia mengalami perkembangan seiring dengan pertumbuhan ekonomi yang menandakan kondisi baik, untuk itu diperlukan kebijakan yang tepat dalam pengelolaanya supaya dapat mendorong investasi sehingga perekonomian Indonesia terus bertumbuh dan berkembang untuk mencampai tujuan akhir berupa kemakmuran dan kesejahteraan masyarakat dalam roda perekonomian.

Untuk memprediksi harga saham terutama saham yang terdaftar di Indeks Harga Saham Gabungan berpengaruh terhadap volatilitas harga saham oleh karena itu hendaknya investor terlebih dahulu mengamati suku bunga, tingkat inflasi, kurs valuta asing dan penelitian ini diharapkan dapat memberikan kontribusi namun dalam prosesnya terdapat beberapa kelemahan yaitu periode pengamatan 3 tahun, variabel yang digunakan perlu ditambahkan dalam variabel independen contohnya diantaraya PDB dan GNP atau dependennya harga saham, return atau ILQ45 serta menggunakan metode analisis yang berbeda dari tahun sebelumnya. Sehingga dapat mengetahui faktor paling dominan yang mempengaruhi harga saham dari volatilitas tersebut.

\section{DAFTAR PUSTAKA \\ Buku :}

Boedie Zvi, Alez Kane, And Marcus Alan J. 1995, "Investment". Second Edition Von Hoffm, Press Incorporation., USA.

Fakhrudin, M dan Sopian Hadianto, M. 2001. "Perangkat Dan Model Analisis Investasi Di Pasar Modal". PT. Elexmedia Komputindo Jakarta.

Ghozali, Imam. 2011. "Aplikasi Analisis Mulitvariate Dengan Program IBM SPSS 19". Edisi lima. Semarang : Universitas Diponegoro.

Gujarati, D. 2003. Basic Econometrics. Mc-Grawhill. New York

Manurung, M, dan Rahardja, P. 2004. Uang, Perbankan, dan Ekonomi Moneter. (Kajian Kontekstual Indonesia). Jakarta: Lembaga Penerbit FE-UI. Munawir.

Sekaran, Uma. 2006. "Research Methods For Business". Salemba Empat Jakarta

Sekaran, Uma. 2014. "Research Methods For Business". Salemba Empat Jakarta

Tabachnick, B.G. 1996. Using Multivariate Statistics. Harper Collin. New York

Tandelilin, Eduardus. 2010. "Portofolio dan Investasi : Teori dan Aplikasi". Edisi 1. Yogyakarta : Kanisius.

Weston J., Fred and Brigham F. Eugene 1994. Essential of Managerial 
Finance, Tenth Edition. New York: The Dryden Press.

\section{Jurnal :}

Maghyereh, A. I. (2002). "Causal relations among stock prices and macroeconomic variables in the small, open economy of Jordan". available at http://ssrn.com/ abstract $=317539$.

Maysami, R. C., Loo, S. W., \& Koh, T. K. (2004). "Co-movement among sector stock market indices and cointegration among dually listed companies". Jurnal Pengurusan 23:33-52.

Murtianingsih. (2012). "Variabel Ekonomi Dan Indeks Harga Gabungan". Jurnal Ekonomi Dan Manajemen Vol. 1 No. 3.

Suramaya Suci Kewal. (2012). Pengaruh Inflasi, Suku Bunga, Kurs, Dan Pertumbuhan PDB Terhadap Indeks Harga Saham Gabungan Jurnal Economia, Volume 8, Nomor 1, April 2012.

\section{Website :}

www. bi.go.id

www.duniainvestasi.com

www.indonesia-investments.com

www.kontan.co.id 